\title{
Interactions Between Rotylenchus reniformis and Pineapple mealybug wilt associated virus-1 in Pineapple
}

\author{
B. S. Sipes, D. M. Sether, and J. S. Hu, University of Hawaii at Manoa, Plant and Environmental Protection Sci- \\ ences, Honolulu, HI 96822
}

\section{ABSTRACT}

Sipes, B. S., Sether, D. M., and Hu, J. S. 2002. Interactions between Rotylenchus reniformis and Pineapple mealybug wilt associated virus-1 in pineapple. Plant Dis. 86:933-938.

The individual and combined effects of Pineapple mealybug wilt associated virus-1 (PMWaV-1) infection in pineapple, Ananas comosus, and Rotylenchus reniformis on pineapple growth were evaluated under greenhouse and field conditions. Under greenhouse conditions, no effect of PMWaV-1 infection on pineapple growth or nematode reproduction was observed. Under field conditions, the interaction of PMWaV-1 and nematodes was evaluated in plant and ratoon crops. In the plant crop, pineapple in plots treated with the nematicide 1,3-dichloropropane showed increased vegetative growth, whereas virus infection had no effect on vegetative growth. Nematodes reduced the average fruit weight $(P=0.01)$, whereas PMWaV-1 infection did not $(P>$ 0.14 ). However, more fruit in the largest size classes (sizes 7 and 8 ) were produced in PMWaV1 -free plots than in PMWaV-1-infected plots $(P=0.03)$. The average fruit weight decreased in the presence of virus or nematodes. The smallest fruits were from PMWaV-1-infected plants infested with $R$. reniformis. More early-ripening fruit (30\%) were produced by plants infected with PMWaV-1 than by PMWaV-free plants $(P<0.05)$. PMWaV-1 infection may be one of the reasons for asynchronous fruit ripening, which is a top limiting factor for pineapple production in Hawaii. In the ratoon crop, PMWaV-1 infection reduced fruit weight by $9 \%(P<0.01)$, whereas nematode effects were similar across treatments $(P>0.10)$. More fruit in the three largest size categories were produced in PMWaV-1-free plots than in PMWaV-1-infected plots $(P<0.01)$. PMWaV-1 infection reduced the number of fruit produced in the ratoon crop $(P<$ $0.02)$. An interaction $(P<0.03)$ between $R$. reniformis and PMWaV-1 infection status was detected in the ratoon crop. The fewest fruit were produced in plots with PMWaV-1-infected plants that were nematode infected.

Additional keywords: closterovirus, mealybug-transmitted, reniform nematode

Pineapple, Ananas comosus (L.) Merr., is a perennial, xerophytic monocot in the Bromeliaceae family (13). Planting materials used for commercial production are typically the crown from the top of the fruits (19). The planted crowns, referred to as the plant crop, will each produce a single pineapple fruit 18 to 20 months after planting (19). Following plant crop harvest, a ratoon crop develops from suckers produced on the stem of the plant crop plants (13). Fruit from the ratoon crop is harvested in approximately 12 to 15 months (19). Pineapple can be affected by many different pests and pathogens (20). Among the most serious are plant-parasitic nematodes and the complex of closteroviruses associated with mealybug wilt of pineapple (MWP). Rotylenchus reniformis and Meloidogyne javanica are the major plant-parasitic nematodes that occur throughout the pineapple growing areas of

Corresponding author: D. M. Sether

E-mail: sether@hawaii.edu

Accepted for publication 23 April 2002.

Publication no. D-2002-0701-01R

(C) 2002 The American Phytopathological Society
Hawaii (20). R. reniformis reduces plant crop yields $(30,31)$ and devastates first ratoon crops (20). Effects of the nematodes are mitigated by an intercycle fallow, preplant soil fumigation, and postplant nematicide applications (30).

Mealybug wilt nearly destroyed the Hawaiian pineapple industry in the early 1900 s (3) and continues to pose a threat to yields $(7,8,21,25,27)$. Two distinct closteroviruses have been found in pineapple plants from Hawaii and around the world $(10,15,24,26,28,34)$. The incidence of Pineapple mealybug wilt associated virus-1 (PMWaV-1) varies from 20 to $100 \%$ in healthy-appearing Hawaiian-grown proprietary selections $(9,28)$. Infection incidences of PMWaV-2 are lower, ranging from 0 to $36 \%$ in the same selections (28). Crowns collected from these selections are used to establish plant crops and, if infected with PMWaVs, serve as a primary virus source in the field. Infections have been perpetuated through this clonal propagation of pineapple for decades $(9,28)$. Both PMWaV-1 and PMWaV-2 are mealybug-transmitted $(24,26,29)$. PMWaV-2 and mealybugs both play a role in MWP symptom induction, whereas PMWaV-1 does not appear to be necessary for symptom development
$(8,24,26)$. Although PMWaV-1 infection may not be directly involved in MWP, its presence correlates with growth reduction in the plant crop (23) and reduces fruit yield in the ratoon crop $(25,27)$. Nematodes and virus infection each affect the profitability and continued cultivation of pineapple in Hawaii.

Impacts of interactions between plant stresses are not uncommon. Nematode interactions with fungi, bacteria, and viruses have been documented to synergistically elicit certain diseases in some species. For example, Meloidogyne and Fusarium together can exacerbate wilts of cotton and tobacco $(4,14,32)$, and Criconemella and Pseudomonas syringae pv. syringae cause short life of peach trees (18). PMWaV-1 infection has a greater reduction on ratoon crop yield in the presence of environmental stress such as drought (25). We investigated the effects of PMWaV-1 infection on $R$. reniformis populations under greenhouse conditions and evaluated the effects of these two pathogens together on pineapple growth, fruit maturation date, and yield in a commercial pineapple field.

\section{MATERIALS AND METHODS}

Greenhouse experiment. An experiment using a completely randomized design was established to determine the effect of PMWaV-1 infection on pineapple growth and reproduction of $R$. reniformis. The experiment was repeated three times. Pineapple crowns were assayed for PMWaV-1 infection using a tissue blot immunoassay (TBIA) with PMWaV-1specific monoclonal antibody (MAb) 35-6$5(9,10)$ and categorized based on \pm infection status. Steam-sterilized soil was placed in $25-\mathrm{cm}$-diameter clay pots. Ten PMWaV-1-free and 10 PMWaV-1-infected pineapple crowns were randomly assigned to the pots for each replicate. Plants were treated with $20-\mathrm{ml}$ aliquots containing 10,000 eggs of $R$. reniformis or sterile water. Plants were grown for 9 months and were then harvested. The D-leaf, which is the largest mature leaf (13), was removed and weighed. Shoots were separated from roots. Fresh weight of shoots and roots was recorded. Roots were shaken in a sodium hydrochlorite solution (11) to extract eggs. A $250 \mathrm{~cm}^{3}$ soil subsample was elutriated to extract nematodes $(2,12)$. Data were analyzed for variance and, where appropriate, means separation procedures were used (SAS Institute, Cary, NC). 
Field experiment. An experiment using a randomized complete block design with treatments arranged factorially and replicated five times was established in a commercial pineapple field on Oahu, HI. Plots of 154 plants were $10 \mathrm{~m}$ long and two beds wide. Each bed consisted of two rows with crowns planted on $26-\mathrm{cm}$ centers. Treatments consisted of PMWaV-1-free or PMWaV-1-infected pineapple crowns and preplanting treatment or no treatment with nematicide. A treatment of 1,3-dichloropropene at $383 \mathrm{~kg}$ a.i./ha was used to establish plots with nondetectable $R$. reniformis populations. Plant heights and Dleaf weights were recorded 6 and 12 months after planting. D-leaves were collected from 10 randomly selected plants in each plot. Mature fruit from the plant crop were harvested at weekly or bimonthly intervals as fruit matured. Virus status was confirmed with TBIA using MAb 35-6-5 specific for PMWaV-1. Weights of fruits with crowns attached (100 per plot) and date of harvest were recorded for plant and ratoon crops. Commercial fresh fruit packing sizes were used to categorize fruit as follows: size 7 (2.6 to $2.9 \mathrm{~kg}$ ); size 8 (2.1 to $2.5 \mathrm{~kg}$ ); size 10 (1.7 to $2.0 \mathrm{~kg}$ ); size 12 (1.4 to $1.6 \mathrm{~kg})$; size 14 (1.2 to $1.3 \mathrm{~kg}$ ); size 16 (1.0 to $1.1 \mathrm{~kg})$; Under $(<1.0 \mathrm{~kg})$; and Over (over $3.0 \mathrm{~kg}$ ). Yield data were analyzed with ANOVA, and means were separated where appropriate (SAS). Height measurements were analyzed with repeated measures ANOVA and orthogonal polynomial contrasts. Wilcoxon rank sum tests were used to compare the percentage of fruit produced in each size class between treatments. Bonferroni multiple comparisons procedure was used to compare confidence intervals of the percentage of plant crop fruit harvested from each treatment for each date. Ripening slopes between intervals were compared with confidence intervals for $\beta$ (5).

\section{RESULTS}

Greenhouse experiment. The effect of PMWaV-1 infection on pineapple growth and nematode reproduction was not significant. Crown weight did not differ between PMWaV-1-free and PMWaVinfected plants at time of planting $(P>$ $0.10)$. D-leaf weights were slightly smaller from PMWaV-1-infected plants, but root weight was slightly greater (Fig. 1). $R$. reniformis reproduction was also similar between treatment groups. More nematode eggs were recovered from PMWaV-1-free plants than from PMWaV-1-infected plants (Fig. 1). The numbers of eggs per $\mathrm{g}$ root was slightly greater from the PMWaV-1infected plants $(P>0.10)$ than from PMWaV-1-free plants.

Field experiment. In the plant crop, absence of nematodes at planting correlated with increased pineapple growth. D-leaves were longer and heavier at 6 months $(P<$ $0.01)$ and 12 months $(P<0.01)$ after plant-

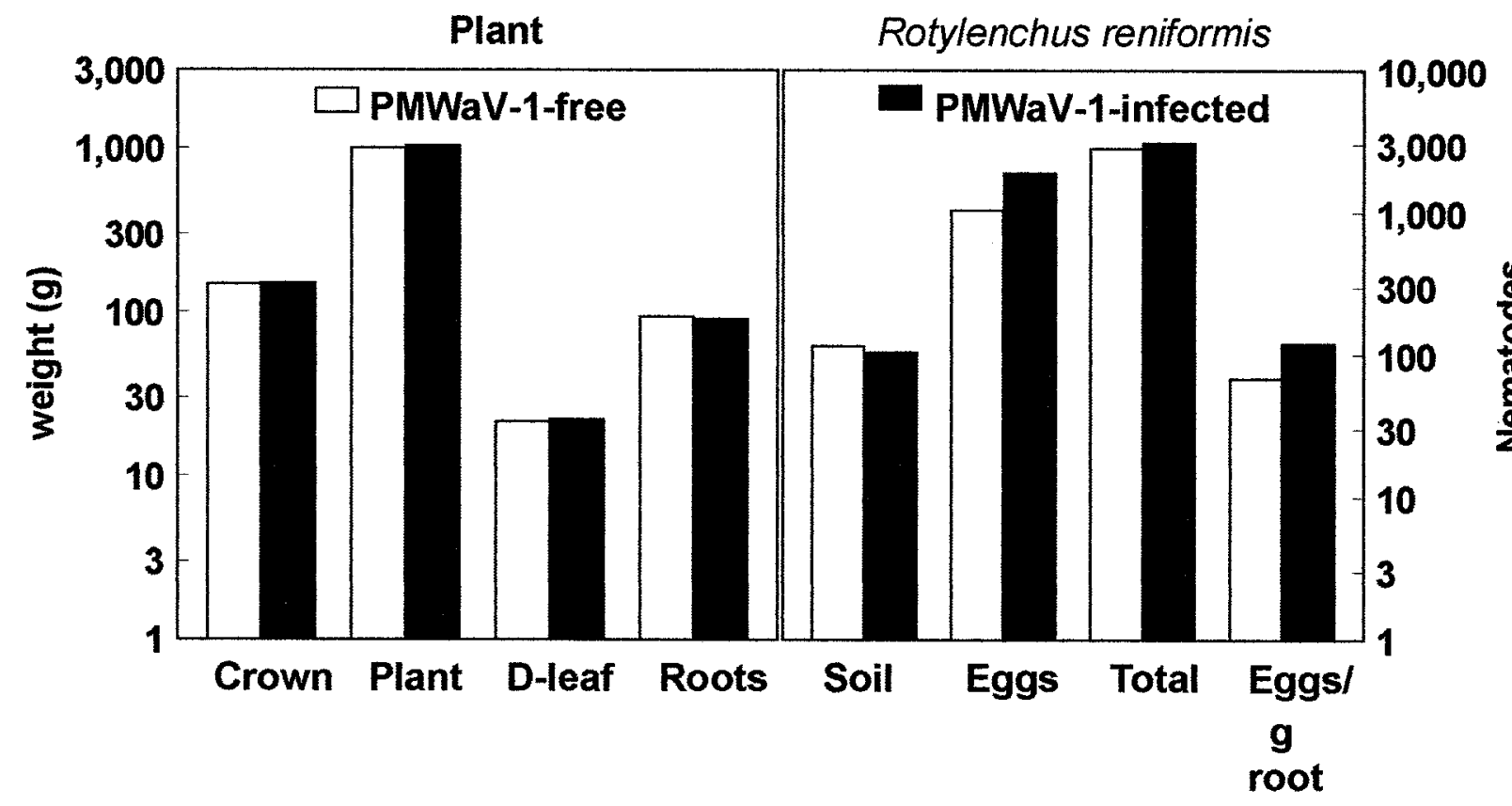

Fig. 1. Left panel: Mean weights of crowns at time of planting (Crown), and of roots and shoots (Plant), D-leaf, and roots 9 months after planting; Right panel: Reniform nematode population on Pineapple mealybug wilt associated virus-1 (PMWaV-1)-free and PMWaV-1-infected pineapple grown under greenhouse conditions for 9 months: number of reniform nematodes elutriated from $250 \mathrm{~cm}^{3}$ (Soil); number of reniform nematode eggs recovered from roots (Eggs), total number of reniform nematodes per plant (Total), and number of reniform nematode eggs per gram of dry root weight (Eggs/g root).

Table 1. Average lengths and weights of pineapple plant D-leaves at 6 and 12 months postplanting, average pineapple fruit weights from plant and ratoon crops, and average number of fruit per treatment plot produced in the ratoon crop across Pineapple mealybug wilt associated virus-1 (PMWaV-1) or nematicide subtreatments

\begin{tabular}{|c|c|c|c|c|c|c|c|}
\hline \multirow[b]{3}{*}{ Treatment } & \multicolumn{4}{|c|}{ D-leaf ${ }^{x}$} & & & \multirow{3}{*}{$\begin{array}{l}\text { No. ratoon } \\
\text { crop fruit }\end{array}$} \\
\hline & \multicolumn{2}{|c|}{6 Months } & \multicolumn{2}{|c|}{12 Months } & \multicolumn{2}{|c|}{ Average fruit weight ${ }^{x}(g)$} & \\
\hline & Length $(\mathrm{cm})$ & Weight (g) & Length $(\mathrm{cm})$ & Weight (g) & Plant crop & Ratoon crop & \\
\hline \multicolumn{8}{|c|}{ PMWaV-1 status } \\
\hline Not infected & $48.8 \mathrm{a}$ & $23.1 \mathrm{a}$ & $94.4 \mathrm{a}$ & $76.5 \mathrm{a}$ & $2,167 \mathrm{~b}$ & $1,641 \mathrm{a}$ & $123 \mathrm{a}$ \\
\hline Infected & $48.7 \mathrm{a}$ & $21.8 \mathrm{a}$ & $92.1 \mathrm{a}$ & $72.1 \mathrm{a}$ & $2,109 \mathrm{~b}$ & $1,486 \mathrm{~b}$ & $100 \mathrm{~b}$ \\
\hline \multicolumn{8}{|l|}{ Nematicide $^{\mathrm{z}}$} \\
\hline Untreated & $47.3 \mathrm{~b}$ & $19.7 \mathrm{~b}$ & $89.7 \mathrm{~b}$ & $69.0 \mathrm{~b}$ & $2,064 \mathrm{~b}$ & $1,593 \mathrm{a}$ & $111 \mathrm{a}$ \\
\hline Treated & $50.3 \mathrm{a}$ & $25.2 \mathrm{a}$ & $97.0 \mathrm{a}$ & $79.6 \mathrm{a}$ & $2,212 \mathrm{a}$ & $1,533 \mathrm{a}$ & $112 \mathrm{a}$ \\
\hline
\end{tabular}

x Numbers followed by different letters within a column are significantly different at $\alpha=0.05$ based on Fisher's LSD and Tukey's studentized range tests.

y Average number of ratoon fruit produced per replicate plot; plant crop fruit numbers were equal (150) between treatments and are not shown.

${ }^{\mathrm{z}}$ Treated plots received a preplant application of 1,3-dichloropropane. 
ing (Table 1), and plant height was greater from plots that received nematicide $(P<$ 0.01) (Table 2). Virus status across nematode treatments was not different for D-leaf lengths or weights at 6 months $(P>0.20)$ or 12 months $(P>0.16)$ after planting (Table 1), or for plant height $(P<0.07)$

(Table 2). Nematode infection of the plants
Table 2. Average plant height during the plant crop, average pineapple fruit weight from the plant and ratoon crops, and the average number of fruit produced in the ratoon crop from plants with and without Pineapple mealybug wilt associated virus-1 (PMWaV-1) and treated or not treated with nematicide

\begin{tabular}{|c|c|c|c|c|c|}
\hline \multirow[b]{2}{*}{ Treatment } & \multicolumn{2}{|c|}{ Plant height $^{\mathrm{x}}(\mathrm{cm})$} & \multicolumn{2}{|c|}{ Fruit weight (g) } & \multirow{2}{*}{$\begin{array}{l}\text { No. ratoon } \\
\text { fruity }\end{array}$} \\
\hline & 6 & 12 & Plant crop & ratoon crop & \\
\hline $\begin{array}{l}\text { PMWaV-1-free/ } \\
\text { nematicide treated }\end{array}$ & 41.4 & $93.9 \mathrm{a}^{\mathrm{z}}$ & $2,225 \mathrm{a}$ & $1,586 \mathrm{~b}$ & $133 \mathrm{a}$ \\
\hline $\begin{array}{l}\text { PMWaV-1-infected/ } \\
\text { nematicide treated }\end{array}$ & 43.4 & $88.4 \mathrm{a}$ & $2,200 \mathrm{ab}$ & $1,480 \mathrm{c}$ & $110 a b$ \\
\hline $\begin{array}{l}\text { PMWaV-1-free/ } \\
\text { no nematicide }\end{array}$ & 36.4 & $77.8 \mathrm{~b}$ & $2,109 \mathrm{bc}$ & $1,696 \mathrm{a}$ & $112 a b$ \\
\hline $\begin{array}{l}\text { PMWaV-1-infected/ } \\
\text { no nematicide }\end{array}$ & 39.6 & $77.1 \mathrm{~b}$ & $2,018 \mathrm{c}$ & $1,491 \mathrm{bc}$ & $90 \mathrm{~b}$ \\
\hline
\end{tabular}

${ }^{x}$ Average plant height at 6 and 12 months postplanting of crowns. Data were analyzed with repeated measures ANOVA.

${ }^{y}$ Average number of fruit produced per plot in the ratoon cycle based on five replicate plots per treatment.

${ }^{\mathrm{z}}$ Numbers followed by different letters within a column are significantly different at $\alpha=0.05$ and $k$ ratio $=100$ based on Fisher's LSD and Waller-Duncan $k$-ratio tests, respectively. across virus treatment reduced the average plant crop fruit weight $(P=0.001)$, whereas PMWaV-1 infection across nematode treatment did not $(P>0.14)$ (Table 1). Fruit from PMWaV-1-free plants in plots that received preplant nematicide treatment were larger than PMWaV-1-free and PMWaV-1-infected plants that did not receive preplant nematicide treatments $(P$ $<0.05$ ) but were not different from PMWaV-1-infected plants given a preplant nematicide treatment (Table 2). Average fruit weight increased as PMWaV-1 infection or nematodes were removed from the plants (Table 2). Interaction between the two pathogens was not significant $(\mathrm{df}=1$; $F=0.79 ; P=0.39$ ). The highest percentage of fruit produced in plots without nematodes or composed of PMWaV-1-free plants was size 8, whereas the highest percentage of fruit produced by plots consisting of PMWaV-1-infected plants with nematodes was the smaller size 10 fruit (Fig. 2). Across nematicide treatments,
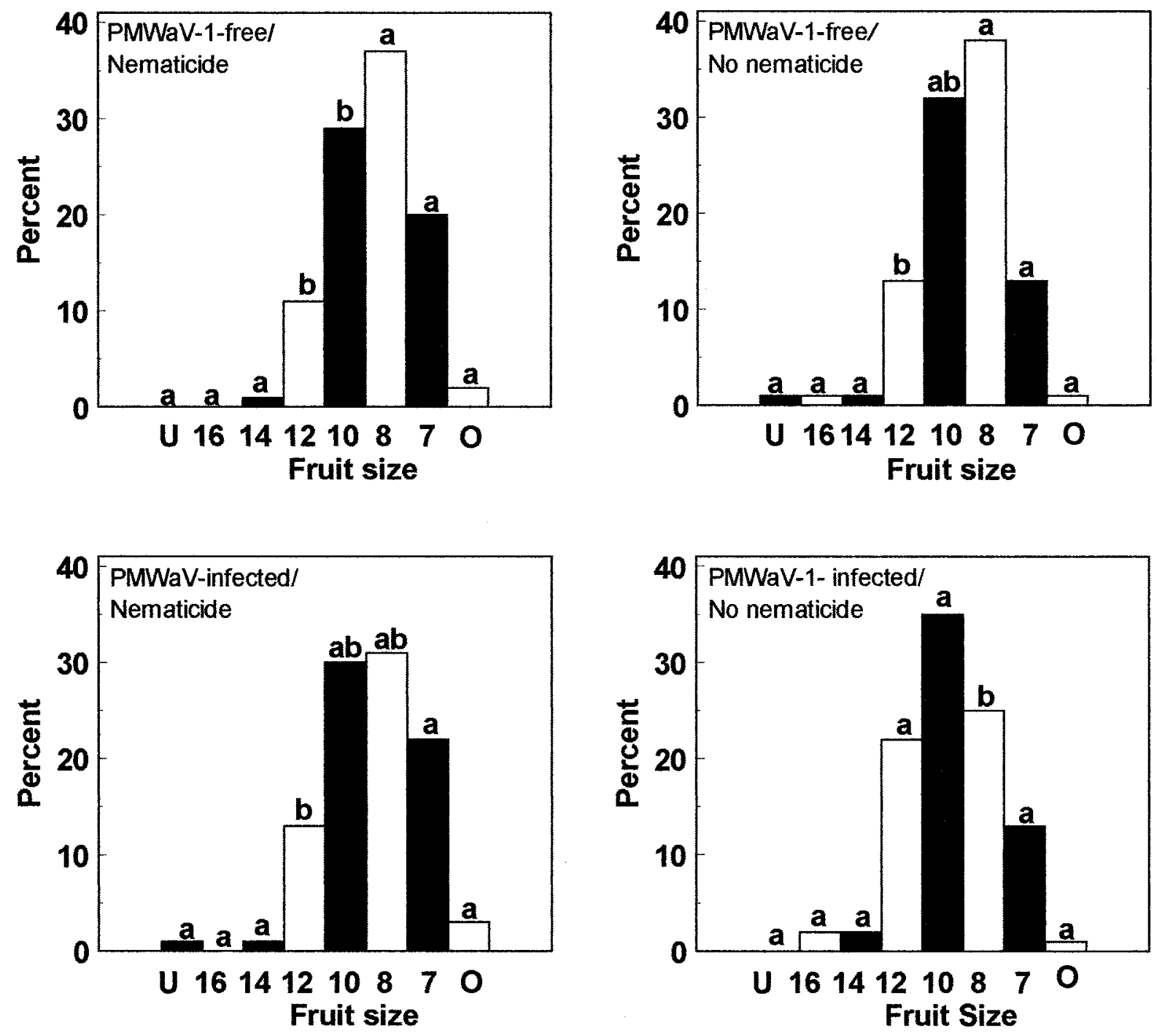

Fig. 2. Frequency distributions of fruit sizes produced in the plant crop under various treatments. Bars of same pattern with different letters are significantly different at $\alpha=0.05$ based on 1-tailed Wilcoxon rank sums tests of replicate plots. Fruit size categories are as follows: 7 ( 2.6 to 2.9 kg); 8 ( 2.1 to $2.5 \mathrm{~kg}) ; 10(1.7$ to $2.0 \mathrm{~kg}) ; 12(1.4$ to $1.6 \mathrm{~kg}) ; 14(1.2$ to $1.3 \mathrm{~kg}) ; 16(1.0$ to $1.1 \mathrm{~kg}) ; \mathrm{U}$ (<1.0 kg); and O (over $3.0 \mathrm{~kg})$. 


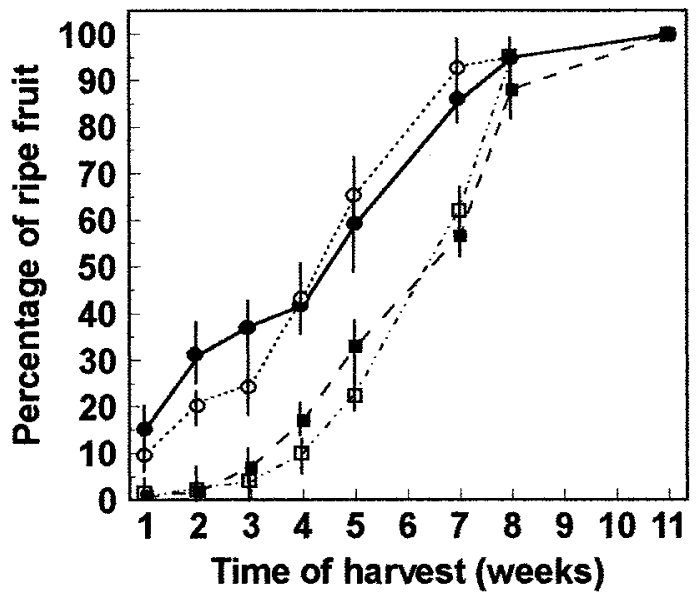

Fig. 3. Percentage of total mature fruit showing yellow shell color harvested at specified intervals from the plant crop. Treatments were $(\bullet)$ Pineapple mealybug wilt associated virus-1 (PMWaV-1)infected/Rotylenchus reniformis; (O) PMWaV-1-infected/no R. reniformis; (ロ) PMWaV-1-free/R. reniformis; ( $\square$ ) PMWaV-1-free/no R. reniformis. Bars represent standard deviations between plots.
PMWaV-1-free plants produced more fruit than PMWaV-1-infected plants when size classes 7 and 8 , or 7,8 , and 10 were combined $(P<0.03$ and $P<0.04$, respectively).

More early maturing fruits $(30 \%)$ were produced by plants infected with PMWaV1 than from PMWaV-1-free plants during the first 4 weeks (Fig. 3). After the fourth week, the slopes representing the rates of fruit maturation were similar between PMWaV-1-infected and PMWaV-1-free plants. The number of early ripening fruit did not differ between nematode treatments after the fifth week of harvest $(P>0.10)$.

In the ratoon crop, PMWaV-1 infection affected yield $(P<0.01)$, whereas preplant nematicide treatment did not $(P>0.10)$. PMWaV-1 infection caused a greater reduction in fruit weight than did presence of nematodes. Across nematicide treatments, PMWaV-1-free plants produced fruit $155 \mathrm{~g}$ (9\%) heavier than fruit from PMWaV-1infected plants (Table 1). The average fruit
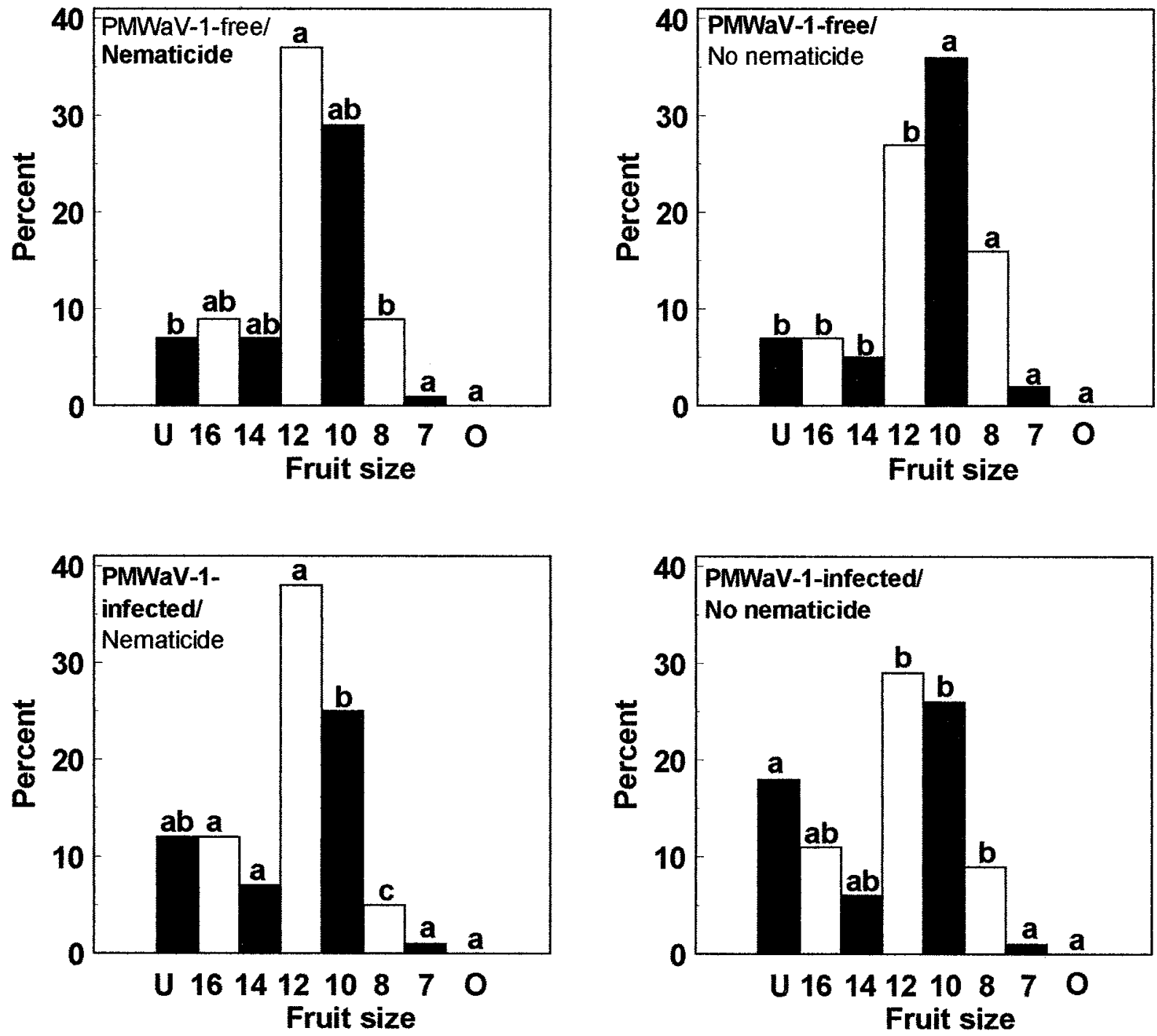

Fig. 4. Frequency distributions of fruit sizes produced in the ratoon crop under various treatments. Bars of same size category with different letters are significantly different at $\alpha=0.05$ based on 1 -tailed Wilcoxon rank sums tests of replicate plots. Fruit size categories are as follows: 7 (2.6 to $2.9 \mathrm{~kg}$ ); 8 (2.1 to $2.5 \mathrm{~kg}$ ); 10 (1.7 to $2.0 \mathrm{~kg}$ ); 12 (1.4 to $1.6 \mathrm{~kg}$ ); 14 (1.2 to $1.3 \mathrm{~kg}$ ); 16 (1.0 to $1.1 \mathrm{~kg}) ; \mathrm{U}$ (<1.0 kg); and O (over $3.0 \mathrm{~kg}$ ). 
weight was greatest in the PMWaV-1-free plots with $R$. reniformis (Table 2). Interaction between the pathogens was not significant (df $=1 ; F=2.14 ; P=0.163$ ). In general, more of the fruits produced in the ratoon crop (Fig. 4) separated into smaller size classes than did the fruits produced in the plant crop (Fig. 2). Across nematicide treatments, a higher percentage of ratoon fruit were produced in PMWaV-1-free plots than in PMWaV-1-infected plots $(P<$ 0.01 ) when sizes 7,8 , and 10 were pooled. Plots that did not receive preplant nematicide treatments produced more fruit in the size 8 (large) category than plots treated with nematicide (Fig. 4). Also, more fruit were produced in the Under and size 16 categories in the PMWaV-infected plots.

The number of fruit produced by the plant crop did not differ between treatments. However, in the ratoon cycle, PMWaV-1 infection across nematode treatment reduced the mean number of fruit produced per plot $(P<0.02)$ (Table $1)$. More ratoon fruit were produced in PMWaV-1-free plots than in PMWaV-1infected plots across nematicide treatment (Table 1). Across virus status, treatment with nematicide did not impact the number of fruit produced in the ratoon cycle $(P>$ 0.94). Interaction between nematode treatment and PMWaV-1 status on fruit number was detected in the ratoon crop ( $P$ $<0.03)$. PMWaV-1 infection with nematodes resulted in fewer ratoon crop fruit produced per plot than PMWaV-1-free plants that received a preplant nematicide treatment during the plant crop (Table 2).

\section{DISCUSSION}

In the pineapple plant crop, $R$. reniformis had the greatest effect on total yields based on weight. The nematode treatments did not have an effect in the ratoon crop. In this crop, nematode populations may have built up in the plots that previously received a preplant nematicide treatment. This buildup may have obscured the yield improvements that could have been realized if postplant nematicides had been used on these plots. PMWaV-1 infection could potentially reduce yields up to $30 \%$ because of early ripening in the plant crop. PMWaV-1 infection did not have an effect on the average fruit weight in the plant crop but caused a reduction in average fruit weight in the ratoon crop. This supports earlier findings with a different $A$. comosus proprietary selection where PMWaV-1 infection reduced yield in the ratoon crop, but effects in the plant crop were minimal (25). The lack of interaction effects between the nematodes and PMWaV-1 suggests additive effects from the two pathogens. Similar effects between drought and PMWaV were observed in a ratoon cycle (25).

PMWaV-1 infection had no effect on reniform nematode reproduction during the first 9 months of growth when pineapple plants were grown in pots in the greenhouse. Thus, the occurrence of PMWaV-1infected plants in the field may not contribute to increased populations of reniform nematode, at least in the early crop cycle. The effect of PMWaV-1 infection on populations of other nematodes such as the rootknot nematode, M. javanica, was not investigated and may be different from $R$. reniformis.

Differences between PMWaV-1-infected and PMWaV-1-free plants with regard to the production of pineapple fruit exhibiting yellow shell color, an indicator of ripeness, were dramatic and have great implications for economic production of pineapple. Early-ripening fruit in the PMWaV-1infected plots required harvesting as much as 10 weeks ahead of the majority of the fruit in PMWaV-1-free plots for the field to obtain maximum yields. Asynchronous fruit maturation resulting in such a broad ripening period is commercially unacceptable. Out of cycle or precocious ripening fruit complicate harvest date predictions and require high harvest labor input due to the scattered nature of the fruits and the difficulty in locating lodged fruit, which results in increased time required to harvest a unit area. Unripe fruit may be damaged during the harvesting of precocious fruit, but if left unharvested, precocious fruit will be overripe when the majority of the fruit in the field are scheduled for harvesting (22). Precocious fruiting has been one of the major limiting factors for pineapple production throughout pineapple growing areas $(16,22,33)$. In our study, if these early-ripening fruit had not been harvested, it would have represented a $30 \%$ loss from PMWaV-1-infected plants. In commercial practice, pineapple is induced to flower (forced) with ethylene-releasing agents such as 2-chloroethylphosphonic acid (ethephon), acetylene, or auxins in order to produce synchronous and predictable fruit production and maturation $(17,33)$. Natural flowering prior to forcing reduces yields and disrupts harvest scheduling. The causes of natural flowering have been correlated with the attainment of a minimum plant size threshold and the presence of short days and cool temperatures $(1,6)$. In our study, although plant weights were not taken, height and D-leaf sizes of PMWaV-1-infected and PMWaV1-free plants were not different between treatments, and plants were exposed to similar night and day temperatures. Thus, the occurrence of early ripening fruit cannot be explained by leaf size or height and may be related to PMWaV-1 infection.

Ratoon crop yields were lower for several reasons. Planting densities were the same for all treatments, but reduced or delayed suckering was observed in the ratoon crop, culminating in reduction of fruit bearing plants at the time of ratoon harvest. Also, in the ratoon crop, more fruit were produced in the size 16 and Under size categories by PMWaV-1-infected plants. Smaller plants typically produce smaller fruit. These small fruit sizes are undesirable for packing and are considered discards by the commercial fresh-fruit packing houses in Hawaii. Higher plant crop and ratoon yields can be produced by the use of PMWaV-1-free planting material.

This study was initiated prior to characterization of a second pineapple closterovirus, PMWaV-2 (15), and production of a PMWaV-2-specific monoclonal antibody (26). PMWaV-2 infection rates in the pineapple cultivar selection used for this study are near $1 \%$ in PMWaV-1-free, healthyappearing plants and less than $1 \%$ in PMWaV-1-infected plants (28). We do not know how PMWaV-2 might interact with nematodes. PMWaV-1-infection increases the number of early, asynchronously maturing fruit by $30 \%$ in the plant crop and reduces pineapple fruit weights by $9 \%$ in the ratoon crop. Thus, elimination of PMWaV-1-infection and the control of $R$. reniformis can lead to maximum pineapple yields.

\section{ACKNOWLEDGMENTS}

We thank C. Oda, the staff at Del Monte Fresh Fruit Hawaii and D. Meyer, G. Nagai, M. Young, H.-P. Li, W. Borth, W. Xie, M. Lu, and M. Xu for their assistance in planting and maintaining the experiment and data collection. We also thank W. Borth, S. Nelson, and K. Rohrbach for their critical reviews of the manuscript. This research was funded, in part, by grants from the State of Hawaii Governor's Agricultural Coordinating Committee contract no. 87-12, from the Hawaii Department of Agriculture contract no. 43754, and by the specific Cooperative Grant agreement 58-5320-5-604 between the USDA-ARS and the University of Hawaii. This is Journal Series no. 4601 of the College of Tropical Agriculture and Human Resources, University of Hawaii, Honolulu.

\section{LITERATURE CITED}

1. Bartholomew, D. P., and Malézieux, E. 1994. Pineapple. Pages 243-291 in: Handbook of Environmental Physiology of Fruit Crops. Vol. 2. B Schaffer and P. Anderson, eds. CRC Press Inc., Boca Raton, FL.

2. Byrd, D. W., Jr., Barker, K. R., Ferris, H., Nusbaum, C. J., Griffin, W. E., Small, R. H., and Stone, C. A. 1976. Two semi-automatic elutriators for extracting nematodes and certain fungi from the soil. J. Nematol. 8:206212.

3. Carter, W. 1933. The pineapple mealy bug, Pseudococcus brevipes, and wilt of pineapples. Phytopathology 23:207-242.

4. DeVay, J. E., Gutierrez, A. P., Pullman, G. S. Wakeman, R. J., Garber, R. H., Jeffers, D. P. Smith, S. N., Goodell, P. B., and Roberts, P. A. 1997. Inoculum densities of Fusarium oxysporum f. sp. vasinfectum and Meloidogyne incognita in relation to the development of Fusarium wilt and the phenology of cotton plants (Gossypium hirsutum). Phytopathology 87:341-346.

5. Devore, J., and Peck, R. 1986. Statistics. The Exploration and Analysis of Data. West Publishing Co., St. Paul, MN.

6. Friend, D. J. C. 1981. Effect of night temperature on flowering and fruit size in pineapple Ananas comosus (L.) Merrill. Bot. Gaz. 142:188-190

7. German, T. L., Ullman, D. E., and Gunash- 
inghe, U. B. 1992. Mealybug wilt of pineapple. Adv. Dis. Vect. Res. 9:241-259.

8. Hu, J. S., and Sether, D. M. 1999. Etiology of mealybug wilt of pineapple. Page 321 in: Abstr. Xth Int. Congr. Virol., Sydney, Australia.

9. Hu, J. S., Sether, D. M., Liu, X. P., Wang, M., Zee, F., and Ullman, D. E. 1997. Use of a tissue blotting immunoassay to examine the distribution of pineapple closterovirus in Hawaii. Plant Dis. 81:1150-1154.

10. Hu, J. S., Sether, D. M., and Ullman, D. E. 1996. Detection of pineapple closterovirus in pineapple plants and mealybugs using monoclonal antibodies. Plant Pathol. 45:829-836.

11. Hussey, R. S., and Barker, K. R. 1973. A comparison of methods of collecting inocula of Meloidogyne spp., including a new technique. Plant Dis. Rep. 57:1025-1028.

12. Jenkins, W. R. 1964. A rapid centrifugalflotation technique for separating nematodes from soil. Plant Dis. Rep. 48:692.

13. Krauss, B. 1948. Anatomy of the vegetative organs of the pineapple, Ananas comosus (L.) Merr. Bot. Rev. 110:159-217.

14. LaMondia, J. A. 1992. Predisposition of broadleaf tobacco to fusarium wilt by early infection with Globodera tabacum or Meloidogyne hapla. J. Nematol. 24:425.

15. Melzer, M. J., Karasev, A. V., Sether, D. M., and $\mathrm{Hu}$, J. S. 2001. Nucleotide sequence, genome organization, and phylogenetic analysis of pineapple mealybug wilt-associated virus2. J. Gen. Virol. 82:1-7.

16. Min, X.-J., and Bartholomew, D. P. 1993. Effects of growth regulators on ethylene production and floral initiation of pineapple. Acta Hortic. 334:101-112.

17. Min, X.-J., and Bartholomew, D. P. 1996. Effect of plant growth regulators on ethylene production, 1-aminocyclopropane-1-carbox- ylic acid oxidase activity, and initiation of inflorescence development of pineapple. J. Plant Growth Regulation 15:121-128.

18. Nyczpir, A. P. 1990. Influence of Criconemella xenoplax and pruning time on short life of peach trees. J. Nematol. 22:97-100.

19. Rohrbach, K. G. 1990. Pineapple: The Plant and Its Culture. Hawaii Institute of Tropical Agriculture and Human Resources, University of Hawaii at Manoa. Hawaii Agricultural Experiment Station, Honolulu, HI.

20. Rohrbach, K. G., and Apt, W. J. 1986. Nematode and disease problems of pineapple. Plant Dis. 70:81-87.

21. Rohrbach, K. G., Beardsley, J. W., German, T. L., Reimer, N. J., and Sanford, W. G. 1988. Mealybug wilt, mealybugs, and ants on pineapple. Plant Dis. 72:558-565

22. Scott, C. H. 1993. The effect of two plant growth regulators on the inhibition of precocious fruiting in pineapple. Acta Hortic. 334:77-82.

23. Sether, D. M., and Hu, J. S. 1998. Corollary analyses of the presence of pineapple mealybug wilt associated virus and the expression of mealybug wilt symptoms, growth reduction, and/or precocious flowering of pineapple. (Abstr.) Phytopathology 88:S80.

24. Sether, D. M., and Hu, J. S. 2000. A closterovirus and mealybug exposure are both necessary components for mealybug wilt of pineapple symptom induction. (Abstr.) Phytopathology 90:S71.

25. Sether, D. M., and Hu, J. S. 2001. The impact of pineapple mealybug wilt-associated virus and reduced irrigation on pineapple yield. Australas. Plant Pathol. 30:31-36.

26. Sether, D. M., and Hu, J. S. Closterovirus infection and mealybug exposure are necessary for the development of mealybug wilt of pineapple disease. Phytopathology. In press

27. Sether, D. M., and Hu, J. S. Yield impact and spread of Pineapple mealybug wilt associated virus-2 and mealybug wilt of pineapple in Hawaii. Plant Dis. In press.

28. Sether, D. M., Karasev, A. V., Okumura, C., Arakawa, C., Zee, F., Kislan, M. M., Busto, J. L., and Hu, J. S. 2001. Differentiation, distribution, and elimination of two different pineapple mealybug wilt-associated viruses found in pineapple. Plant Dis. 85:856-864.

29. Sether, D. M. Ullman, D. E and $\mathrm{Hu}, \mathrm{J}$. S 1998. Transmission of pineapple mealybug wilt-associated virus by two species of mealybug (Dysmicoccus spp.). Phytopathology $88: 1224-1230$.

30. Sipes, B. S., and Schmitt, D. P. 1994. Population fluctuations of Rotylenchus reniformis in pineapple fields and the effect of the nematode on fruit yield. Plant Dis. 78:895-898.

31. Sipes, B. S., and Schmitt, D. P. 1995. Control of Rotylenchulus reniformis in pineapple with emusifiable 1,3-dichloropropene. Plant Dis. 80:571-574.

32. Starr, J. L., Jeger, M. J., Martyn, R. D., and Schilling, K. 1989. Effects of Meloidogyne incognita and Fusarium oxysporum f. sp. vasinfectum on plant mortality and yield of cotton. Phytopathology 79:640-646.

33. Turnbull, C. G. N., Sinclair, E. R., Anderson, K. L., Nissen, R. J., Shorter, A. J., and Lanham, T. E. 1999. Routes of ethephon uptake in pineapple (Ananus comosus) and reasons for failure of flower induction. J. Plant Growth Regulation 18:145-152.

34. Wakman, W., Teakle, D. S., Thomas, J. E., and Dietzgen, R. G. 1995. Presence of a clostero-like virus and a bacilliform virus in pineapple plants in Australia. Australas. J. Agric. Res. 46:947-958.

\section{ERRATUM / Volume 86, Number 9}

In the article "Interactions Between Rotylenchus reniformis and Pineapple mealybug wilt associated virus-1 in Pineapple," by B. S. Sipes, D. M. Sether, and J. S. Hu, pages 933-938, the genus Rotylenchulus was inadvertently misspelled Rotylenchus. The reniform nematode, Rotylenchulus reniformis, was the studied organism. All instances of Rotylenchus reniformis in the manuscript, figures, and literature cited should correctly read Rotylenchulus reniformis. 